\title{
STUDIES ON THE IDENTIFICATION OF A FOLATE COMPOUND OF HUMAN SERUM*
}

\author{
By VICTOR HERBERT, ALLAN R. LARRABEE † AND JOHN M. BUCHANAN \\ (From the Thorndike Memorial Laboratory and Second and Fourth (Harvard) Medical Serv- \\ ices, Boston City Hospital; Department of Medicine, Harvard Medical School, Boston; \\ and the Division of Biochemistry, Department of Biology, Massachusetts Insti- \\ tute of Technology, Cambridge, Mass.)
}

(Submitted for publication May 10, 1961 ; accepted January 25, 1962)

Human serum contains folate (pteroylglutamate) compounds that support the growth of Lactobacillus casei but not Streptococcus faecalis or Leuconostoc citrovorum (Pediococcus cerevisiae) (1). It has been generally accepted that any compound having folic acid activity for $L$. casei but not for $S$. faecalis must be a triglutamate (or polyglutamate) (1-4). On the basis of this similarity, serum folate compounds were considered to be pteroylpolyglutamates. Larrabee, Buchanan, Rosenthal and Cathou $(5,6)$ recently have isolated a monoglutamate $\left(\mathrm{N}^{5}\right.$-methyl tetrahydrofolate) as an intermediate of methionine biosynthesis, and Keresztesy and Donaldson $(7,8)$ have isolated a compound with similar properties (prefolic A) from horse liver. Both compounds exhibit the same response in growth to the three organisms as that shown by the serum folate derivative. This communication reports evidence that the $L$. case $i$-active material of serum is the monoglutamate, $\mathrm{N}^{5}$-methyl tetrahydrofolate.

\section{MATERIALS AND METHODS}

Normal human serum was obtained from healthy young adult males as previously described (1).

Hog kidney conjugase $(9,10)$ was prepared as described to us by Wood and Hitchings (11) with several minor modifications. Fresh hog kidneys (285 g) were defatted and minced in $200 \mathrm{ml}$ of distilled water in a Waring Blendor for 45 seconds. This suspension was incubated under toluene at $37^{\circ} \mathrm{C}$ for 4 hours and then at room temperature overnight. Thirty $\mathrm{ml}$ of distilled water was added, and the coarse aggregates of fat were

* This investigation was supported by Grant A-3853 (C2) from the National Institutes of Health, Bethesda, Md.; by grants from the National Vitamin Foundation and from Eli Lilly and Co.; and by grants from the National Science Foundation and the Nutrition Foundation.

$\dagger$ Predoctoral Fellow of the National Science Foundation (1958-1960) and of the National Institutes of Health (1961-2). removed by filtration through gauze. The material was then centrifuged for 5 minutes in an International clinical centrifuge. The supernatant fluid was decanted and stirred with $4.5 \mathrm{~g}$ of Supercel for 30 minutes. After centrifugation the supernatant solution was decanted into $25 \mathrm{ml}$ of a suspension of calcium phosphate gel $(0.31 \mathrm{~g}$ per $\mathrm{ml}$ ), stirred for 30 minutes, and centrifuged. The supernatant fluid was treated with $2 \mathrm{~g}$ of Darco $\mathrm{G} 60$ activated charcoal ${ }^{1}$ per $100 \mathrm{ml}$ of solution, mixed for 30 minutes, and centrifuged at $3,000 \mathrm{rpm}$ as described before. The supernatant solution was then centrifuged at $30,000 \mathrm{rpm}$ for 30 minutes in a Spinco model $\mathrm{L}$ centrifuge. The clear, red, supernatant solution was stored frozen overnight at $-17^{\circ} \mathrm{C}$, thawed the next day and centrifuged at $10,000 \mathrm{rpm}$ for 10 minutes. The supernatant solution was the hog kidney conjugase used in this study. The final centrifugation proved necessary to remove a contaminant containing "bound" folic acid activity.

Chicken pancreas conjugase $(10,12,13)$ was prepared by dissolving $2 \mathrm{mg}$ of desiccated chicken pancreas (Difco Laboratories) per $\mathrm{ml}$ of water (14). The water solution of desiccated pancreas was centrifuged before use. The supernatant solution was the preparation of chicken pancreas conjugase used in this study.

$N^{5}$-methyl tetrahydrofolate is an intermediate of methionine biosynthesis isolated by Larrabee and Buchanan ( 5 , 6 ) and was prepared by their procedure (6). It did not replace folic acid and $\mathrm{N}^{5}$-formyl tetrahydrofolate as a growth factor for $S$. faecalis and $L$. citrovorum, respectively (6). Since on hydrolysis with $6 \mathrm{~N} \mathrm{HCl}$ at $110^{\circ} \mathrm{C}$ this compound yielded 1 mole glutamate per mole of $\mathrm{N}$-methyl group, it is a monoglutamate.

Teropterin (pteroyltriglutamic acid) ${ }^{2}$ had been stored as a dry powder since 1950 in an amber bottle at $4^{\circ} \mathrm{C}$; $5 \mathrm{mg}$ was dissolved in a mixture of $40 \mathrm{ml}$ of $0.01 \mathrm{~N} \mathrm{NaOH}$ and $10 \mathrm{ml}$ of absolute ethanol. Appropriate dilutions were made with deionized water.

$N^{5}$-methyl tetrahydropteroyltriglutamate was prepared from pteroyltriglutamic acid (Teropterin) by a modification of the procedure of Keresztesy and Donaldson (7) for the synthesis of $\mathrm{N}^{5}$-methyl tetrahydropteroyl monoglutamate from folate.

1 Generously provided by Darco Department, Atlas Powder Co., New York, N. Y.

${ }^{2}$ Kindly provided by Dr. T. H. Jukes and Dr. E. L. R. Stokstad, Lederle Laboratories, Pearl River, N. Y. 
Microbiologic assays with L. casei, S. faecalis, and $L$. citrovorum have been described (1). Activity for the first two organisms was measured against a folic acid standard; activity for L. citrovorum was measured against the calcium salt of synthetic $\mathrm{N}^{5}$-formyl tetrahydrofolate. ${ }^{2}$ Incubation of substrates with conjugase was performed at the optimal $\mathrm{pH}$ for each conjugase (hog

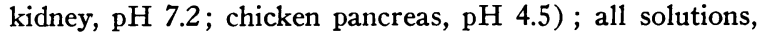
however, were adjusted to $\mathrm{pH} 6.1$ before microbiological assay.

The folic acid activity of serum was concentrated by a method similar to that applied by Usdin (2) for the concentration of blood folic acid activity. To $500-\mathrm{ml}$ aliquots of fresh normal human plasma was added $5 \mathrm{~g}$ of Darco G 60 activated charcoal and $5 \mathrm{~g}$ of sodium ascorbate. This mixture was refrigerated at $6^{\circ} \mathrm{C}$ for 1 hour with gentle shaking, and then was passed through Whatman no. 2 filter paper on a Buchner funnel. Folic acid activity was eluted from the charcoal by treatment of the latter with a solution containing $100 \mathrm{ml}$ of concentrated $\mathrm{NH}_{4} \mathrm{OH}$, $400 \mathrm{ml}$ of deionized water, and $500 \mathrm{ml}$ of ethanol. The charcoal was removed by filtration through Whatman no. 2 filter paper and the filtrate was evaporated to dryness in a rotary flash evaporator. Folic acid activity was extracted from the dried residue with three $2-\mathrm{ml}$ aliquots of $0.001 \mathrm{M}$ ammonium carbonate. The insoluble material was removed by centrifugation for 5 minutes in a clinical centrifuge and discarded.

Since the high salt concentration of the dark ambercolored concentrate interfered with paper chromatography, filtration with dextran gel (Sephadex G-25 medium ${ }^{3}$ ) was employed to separate most of the salts from the folate activity. Three $\mathrm{ml}$ of the viscous concentrate was diluted with an equal volume of water and placed on a column of Sephadex $(2 \times 26 \mathrm{~cm})$. The column was prepared as described by Flodin (15) and eluted with $0.001 \mathrm{M} \mathrm{Na} \mathrm{HPO}_{4} \cdot 7 \mathrm{H}_{2} \mathrm{O}$. Fractions of $2 \mathrm{ml}$ were collected; compounds active for $L$. case $i$ were concentrated in fractions 36 through 48 . Fraction 44 , which had maximal activity, was concentrated tenfold in vacuo, and used for chromatographic studies.

Paper chromatography was done on Whatman no. 1 paper $(18 \times 30 \mathrm{~cm})$. The sheets were spotted with 0.50 $\mu 1$ aliquots of 7 to $10 \times 10^{-5} \mathrm{M}$ solutions of synthetic sodium folate, $\mathrm{N}^{5}$-formyl tetrahydrofolate, chemically prepared $\mathrm{N}^{3}$-methyl tetrahydropteroyltriglutamate, enzymatically prepared $\mathrm{N}^{5}$-methyl tetrahydrofolate, and with $2-\mu 1$ aliquots of serum concentrate. Four developing solvent systems were used : 1) saturated $\mathrm{Na}_{2} \mathrm{HPO}_{4} \cdot 7 \mathrm{H}_{2} \mathrm{O} ; 2$ ) onethird saturated $\mathrm{Na}_{2} \mathrm{HPO}_{4} \cdot 7 \mathrm{H}_{2} \mathrm{O}$ : benzyl alcohol $(2: 1$, vol/ vol; aqueous phase used) ; 3) 5 per cent citric acid brought to $\mathrm{pH} 9$ with concentrated $\mathrm{NH}_{4} \mathrm{OH}$ : isoamyl alcohol (2:1, $\mathrm{vol} / \mathrm{vol}$; both phases used) ; 4) $0.10 \mathrm{M}$ sodium bicarbonate buffer, $\mathrm{pH} 9.3$, containing $6 \mathrm{mg}$ of ascorbic acid per ml. Similar solvent systems have been used by others $(2,16,17)$. After approximately 3 hours of development by the ascending method, the paper chromatograms were allowed to dry in a hood.

3 Purchased from Pharmacia, Uppsala, Sweden.
TABLE I

Release of $S$. faecalis activity from Teropterin by chicken pancreas conjugase or by hog kidney conjugase *

\begin{tabular}{lcc}
\hline \multirow{2}{*}{ Experimental preparations } & \multicolumn{2}{c}{ Folic acid activity } \\
\cline { 2 - 3 } & L. casei $\quad$ S. faecalis \\
\hline & \multicolumn{2}{c}{$m \mu g / m l$} \\
1. 10 & 34 & 4.3 \\
2. Hog kidney conjugase $\dagger$ & 4 & 2.6 \\
3. Chicken pancreas conjugase & 8.5 & 5.3 \\
4. No. 1 + no. 2 & 31 & 16.4 \\
5. No. $1+$ no. 3 & 47 & 48 \\
\hline
\end{tabular}

* All samples were preincubated for 18 hours at $37^{\circ} \mathrm{C}$ under $1 \mathrm{ml}$ toluene with $350 \mathrm{mg}$ per $100 \mathrm{ml}$ ascorbic acid prior to assay.

† The hog kidney conjugase was diluted to 30 per cent of original concentration with deionized water; $1 \mathrm{ml}$ was used in the assays. $\ddagger 0.5 \mathrm{ml}$

Bioautography was done as follows: a fresh 7- to 10hour culture of $L$. casei was grown in $10 \mathrm{ml}$ of basal medium ${ }^{4}$ to which had been added $10^{-7} \mathrm{~g}$ of folic acid as the sodium salt. The bacteria were separated by centrifugation for 5 minutes in a clinical centrifuge. The supernatant solution was discarded, and the organisms were resuspended in $8 \mathrm{ml}$ of 0.9 per cent $\mathrm{NaCl}$. A mixture of $100 \mathrm{ml}$ of basal medium, $100 \mathrm{ml}$ of water, $1 \mathrm{~g}$ of sodium ascorbate, and $4 \mathrm{~g}$ of Bacto-Difco agar ${ }^{5}$ was autoclaved and immediately placed in a water bath at $45^{\circ} \mathrm{C}$. The resuspended $L$. casei culture $(8 \mathrm{ml})$ was added after 10 minutes. This inoculated solution was poured into a sterile glass tray $(20 \times 36 \mathrm{~cm})$ and allowed to solidify. The tray was covered with a lid made from aluminum sheet. A developed paper chromatogram was placed on the surface of the moist agar for 2 minutes and then removed and dried. The tray was incubated at $30^{\circ} \mathrm{C}$ for 12 to 18 hours. At this time the zones of dense L. case $i$ growth were clearly visible in dim light and were traced on the dried paper chromatogram.

\section{RESULTS}

Test of conjugase activity. Teropterin was chosen as a substrate to test the activity of the prepared conjugases. Marked degradation of our Teropterin sample apparently had occurred during its storage for 11 years (a preparation of Teropterin is not conmercially available at the present time). Table I demonstrates that this sample of Teropterin has only one-third of its original activity. Furthermore, only one-third of this remaining activity was made available to $S$. faecalis by hog kidney conjugase at the concentration of enzyme tested, although all of this remaining activity was made available by chicken pancreas conjugase under our experimental conditions.

${ }^{4} L$. casei folic acid assay medium, purchased from Baltimore Biological Laboratory, Baltimore, Md. (1).

5 Purchased from Difco Laboratories, Detroit, Mich. 
TABLE II

Failure of hog kidney or chicken pancreas conjugase to make folic acid activity in human serum available to $S$. faecalis or L. citrovorum *

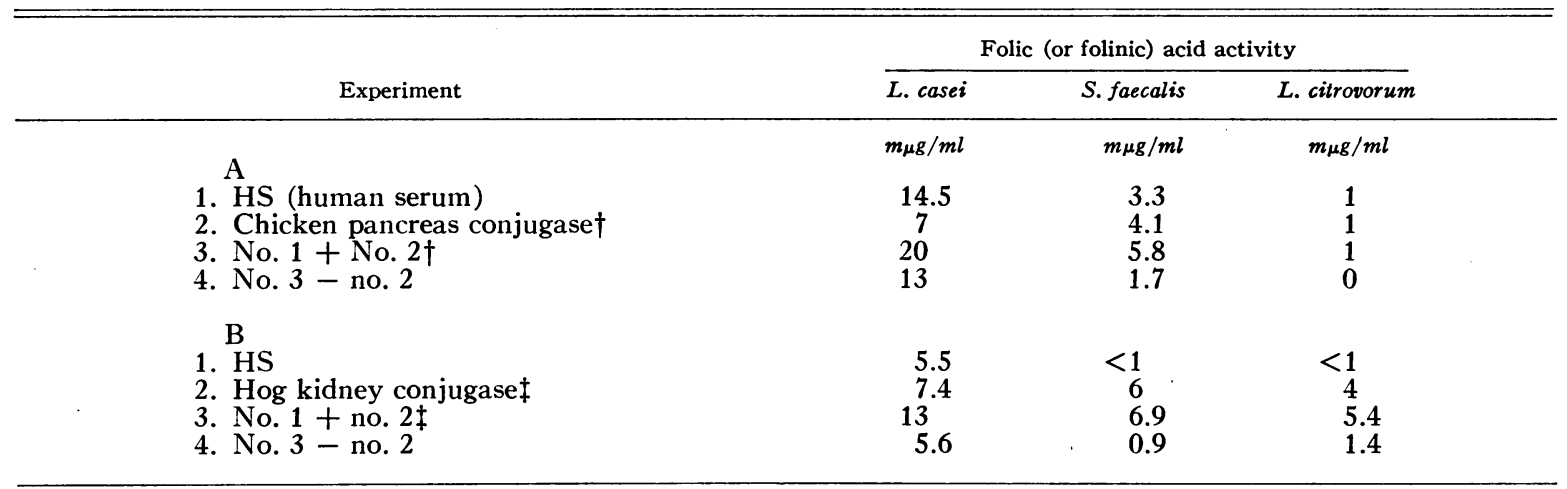

* All samples were preincubated for 18 hours at $37^{\circ} \mathrm{C}$ under $2 \mathrm{ml}$ toluene with $350 \mathrm{mg}$ per $100 \mathrm{ml}$ ascorbic buffer (1) prior to assay.

$+0.5 \mathrm{ml}$.

$\ddagger 1 \mathrm{ml}$.

Level of folate compounds in serum and effect of conjugase preparations. As shown in Table II, an analysis has been made for the levels of folate compounds present in normal human serum. The results of these experiments demonstrate that the folate compounds of serum support the growth of $L$. case $i$ to a much greater extent than they do the growth of $S$. faecalis or L. citrovorum. Other investigators have also reported the existence of classes of folate compounds in blood and other tissues with these same characteristics as growth factors for the three organisms $(2,7,8)$. Since some polyglutamates of folic acid also support the growth of $L$. casei but not that of $S$. faecalis or L. citrovorum, we have incubated serum with crude preparations of chicken pancreas and hog kidney conjugase. If the unknown folate compounds of serum were polyglutamates, it might be expected that conversion to the monoglutamates by the action of conjugase would make them available to $S$. faecalis or $L$. citrovorum. The results of experiments in which normal human serum has been treated with preparations of conjugase are included in Table II. Incubation of normal human serum with either conjugase preparation does not result in the appearance of folate compounds that serve as growth factors for any of the three organisms beyond that level found in the untreated serum. These experiments therefore eliminate, as components of human serum, polyglutamates of folic acid or its derivatives known to be attacked by these conjugases.
The data therefore leave the possibilities that 1) the folate compound of human serum is a monoglutamate such as $\mathrm{N}^{5}$-methyl tetrahydrofolate which, as shown in Table III, serves as a growth factor for $L$. casei but not for the other two organisms; or 2) the folate compound of serum is a polyglutamate which is not attacked by conjugase or which is converted into a product with the same growth characteristics as the initial substrate. In order to distinguish between these possibilities, both $\mathrm{N}^{5}$-methyl tetrahydropteroylglutamate and $\mathrm{N}^{5}$-methyl tetrahydropteroyltriglutamate were prepared and compared with the folate compound of human serum by chromatographic analysis.

Tentative identification of a folate component of serum. The folate activity of serum was adsorbed on Norite, eluted, and concentrated as described in Materials and Methods. The concentrated serum extract was tested for microbiological activity; $5 \mu$ of the concentrate contained $78 \mathrm{~m} \mu \mathrm{g}$ of "folate activity" for $L$. casei and $4.7 \mathrm{~m} \mu \mathrm{g}$ for S. faecalis. In Table IV a comparison has been

TABLE III

Folic (and folinic) acid activity of $\mathrm{N}^{5}$-methyl tetrahydrofolate for L. casei, $S$. faecalis, and L. citrovorum

\begin{tabular}{cccc}
\hline \hline \multirow{2}{*}{$\begin{array}{c}\text { Approximate quan- } \\
\text { tity of N5-methyl } \\
\text { tetrahydrofolate }\end{array}$} & \multicolumn{2}{c}{ Folic (or folinic) acid activity } \\
\cline { 2 - 4 }$m \mu g$ & L. casei & S. faecalis & L. citrovorum \\
\hline 13 & 17 & $m \mu g$ & $m \mu g$ \\
39 & 61 & 3.9 & 1.25 \\
& & & \\
\hline
\end{tabular}


TABLE IV

Comparison of $R f$ values of serum folic acid activity and other folate compounds

\begin{tabular}{|c|c|c|c|c|}
\hline \multirow[b]{2}{*}{ Material } & \multicolumn{4}{|c|}{ Rf in solvent system* } \\
\hline & 1 & 2 & 3 & 4 \\
\hline $\begin{array}{l}\text { Concentrated serum folate activity } \\
N^{5} \text {-methyl tetrahydrofolate } \\
\text { Co-spotted concentrated serum folate }\end{array}$ & $\begin{array}{l}0.76 \\
0.79\end{array}$ & $\begin{array}{l}0.84 \\
0.86\end{array}$ & $\begin{array}{l}0.80 \\
0.82\end{array}$ & $\begin{array}{l}0.91 \\
0.92\end{array}$ \\
\hline $\begin{array}{l}\text { Folic acid }+\mathrm{N}^{5} \text {-methyl tetrahydrofolate } \\
N^{5} \text {-formyl tetrahydrofolate } \\
N^{5} \text {-methyl tetrahydropteroyltriglutamate }\end{array}$ & $\begin{array}{l}0.76 \\
0.14 \\
0.56 \\
0.90\end{array}$ & $\begin{array}{l}0.85 \\
0.49 \\
0.73 \\
0.96\end{array}$ & $\begin{array}{l}0.80 \\
0.19 \\
0.60\end{array}$ & \\
\hline
\end{tabular}

* See text for description.

The dihydro and tetrahydro forms migrated identically in all four and therefore could not be distinguished by paper chromatography (6).

made of the migration of this product with that of other known folate compounds on Whatman no. 1 paper with a variety of developing solvents. The unknown folate activity migrates as a single component in all four buffer systems and with an $\mathrm{Rf}$ value similar to that of $\mathrm{N}^{5}$-methyl tetrahydrofolate. When the serum concentrate is mixed with a solution of $\mathrm{N}^{5}$-methyl tetrahydrofolate and then spotted on paper, only one spot is found after development of the chromatogram with any one of the four solvent systems. The $\mathrm{Rf}$ value of the materials of the mixed solution is the same as the $\mathrm{Rf}$ of the $\mathrm{N}^{5}$-methyl tetrahydrofolate tested separately.

Although the mono- and triglutamates of $\mathrm{N}^{5}$ methyl tetrahydropteroic acid cannot be distinguished from each other on the basis of their growth-promoting properties for the three microorganisms, they may be identified by paper chromatographic analysis. With solvents 1 and 2 (Table IV) the triglutamate migrates more rapidly than does the monoglutamate or the folate compound of human serum. These chromatographic comparisons thus eliminate the triglutamate as the folate component of human serum and provide strong evidence that the folate component is the monoglutamate, $\mathrm{N}^{5}$-methyl tetrahydrofolate. This identification, however, must be held as tentative until sufficient material has been isolated from serum for determination of its spectral characteristics and its ability to serve as a substrate for methionine biosynthesis.

\section{DISCUSSION}

These studies as well as those of others (7) have led to the correction of a previous erroneous assumption that the only folate compounds that support the growth of $L$. casei but not $S$. faecalis or L. citrovorum are di- or triglutamates of pteroic acid. The fact that the $\mathrm{N}^{5}$-methyl tetrahydrofolate supports the growth preferably of $L$. case $i$ is an obvious exception to the previous assumption.

Liver also contains $\mathrm{N}^{5}$-methyl tetrahydrofolate as an important folate constituent. Keresztesy and Donaldson $(7,8,18)$ have isolated from horse liver a monoglutamate compound (prefolic A) which supports growth of $L$. case $i$ but not of $S$. faecalis or L. citrovorum. Silverman, Law and Kaufman (19) have shown that profolic A is the major folate constituent of mouse liver. Moreover, extracts, of human liver possess marked growth activity for $L$. case $i$ but little for $S$. faecalis or L. citrovorum (20). A recent comparison of the chemical and physical properties of prefolic $A$ and $\mathrm{N}^{5}$-methyl tetrahydrofolate shows that they are undoubtedly the same (6). The experiments of these several laboratories thus provide convincing evidence that $\mathrm{N}^{5}$-methyl tetrahydrofolate is a major constituent of at least two tissues, namely liver and serum, and has an important metabolic function in the synthesis of methyl-containing compounds such as methionine and, indirectly, choline (21).

\section{SUMMARY}

1. Folic acid activity in human serum for $\mathrm{Lac}$ tobacillus case i is not made available to Streptococcus faecalis or Leuconostoc citrovorum by the action of hog kidney or chicken pancreas conjugase.

2. A new intermediate of methionine biosynthesis, $\mathrm{N}^{5}$-methyl tetrahydrofolic acid, has marked folic acid activity for $L$. casei but relatively little for $S$. faecalis or L. citrovorum. The fact that this material is a monoglutamate indicates the existence of a previously unknown class of folic acid-active materials: monoglutamates microbiologically active for $L$. casei, but relatively inactive for $S$. faecalis or $L$. citrovorum.

3. The possibility that folic acid activity in human serum may be due largely to such a monoglutamate form is supported by the demonstration that a concentrate of serum folic acid activity and $\mathrm{N}^{5}$-methyl tetrahydrofolate migrates identically in four different solvent systems. 


\section{ACKNOWLEDGMENT}

The authors are indebted to Mrs. Rebecca Fisher Dunn, Mrs. Barbara Bean Mummey, Miss Brenda Conti, and Miss Nancy Cunneen for technical assistance and to Dr. Jane Desforges (Boston City Hospital) and Dr. Sherwin Kevy (Children's Hospital Medical Center) for human blood plasma.

\section{REFERENCES}

1. Herbert, V. The assay and nature of folic acid activity in human serum. J. clin. Invest. 1961, 40, 81.

2. Usdin, E. Blood folic acid studies. VI. Chromatographic resolution of folic acid-active substances obtained from blood. J. biol. Chem. 1959, 234, 2373.

3. Stokstad, E. L. R. Pteroylglutamic acid in The Vitamins, Chemistry, Physiology, Pathology, W. H. Sebrell, Jr. and R. S. Harris, Eds. New York, Academic Press, 1954, vol. III, pp. 89-217.

4. Rabinowitz, J. C. Folic acid in The Enzymes, 2nd ed., P. D. Boyer, H. Lardy and K. Myrback, Eds. New York, Academic Press, 1960, vol. 2, pp. 185252.

5. Larrabee, A. R., and Buchanan, J. M. A new intermediate of methionine biosynthesis. Fed. Proc. 1961, $20,9$.

6. Larrabee, A. R., Rosenthal, S., Cathou, R. E., and Buchanan, J. M. A methylated derivative of tetrahydrofolate as an intermediate of methionine biosynthesis. J. Amer. chem. Soc. 1961, 83, 4094.

7. Keresztesy, J. C., and Donaldson, K. O. Synthetic prefolic A. Biochem. biophys. Res. Com. 1961, 5, 286.

8. Donaldson, K. O., and Keresztesy, J. C. Further evidence on the nature of prefolic A. Biochem. biophys. Res. Com. 1961, 5, 289.

9. Olson, O. E., Fager, E. E. C., Burris, R. H., and Elvehjem, C. A. The use of a hog kidney conjugase in the assay of plant materials for folic acid. Arch. Biochem. 1948, 18, 261.
10. Broquist, H. P. Folic acid conjugase in Methods in Enzymology, S. P. Colowick and N. O. Kaplan, Eds. New York, Academic Press, 1955, vol. II, pp. 629-631.

11. Wood, R. C., and Hitchings, G. H. Personal communication.

12. Mims, V., and Laskowski, M. Studies on vitamin $B_{c}$ conjugase from chicken pancreas. J. biol. Chem. 1945, 160, 493.

13. Dabrowska, W., Kazenko, A., and Laskowski, M. Concerning the specificity of chicken pancreas conjugase. Science 1949, 110, 95.

14. Association of Official Agricultural Chemists. Official Methods of Analysis of the Association of Official Agricultural Chemists, 8th ed. Washington, D.C., 1955.

15. Flodin, P. Methodological aspects of gel filtration with special reference to desalting operations. J. Chromatog. 1961, 5, 103.

16. Wieland, O. P., Hutchings, B. L., and Williams, J. H. Studies on the natural occurrence of folic acid and the citrovorum factor. Arch. Biochem. 1952, 40, 205.

17. Iwai, K., and Nakagawa, S. Studies on folic acid group in plant tissues. IX. On the members of folic acid group in green leaves. Mem. res. Inst. Food Sci. (Kyoto) 1958, 15, 40.

18. Donaldson, K. O., and Keresztesy, J. C. Naturally occurring forms of folic acid. I. "Prefolic A": Preparation of concentrate and enzymatic conversion to citrovorum factor. J. biol. Chem. 1959, 234, 3235.

19. Silverman, M., Law, L. W., and Kaufman, B. The distribution of folic acid activities in lines of leukemic cells of the mouse. J. biol. Chem. 1961, 236, 2530.

20. Romine, M. K. The folic acid activity of human livers as measured with Lactobacillus casei. J. Vitaminol. 1960, 6, 196.

21. Alexander, G. J. Choline biogenesis-III. The origin of the three methyl groups. J. Neurochem. 1961, 6, 292. 